\title{
НАЦОНАЛЬНИЙ МЕТАНАРАТИВ І ПРОЗА ОЛЕНИ ПЧІЛКИ
}

\author{
Моклиця М. В.
}

\section{ВСТУП}

Культура постійно рефлексує над власними дискурсами, якоюсь мірою їх переосмислює, а якоюсь - доповнює, ревізує. Українським літературознавцям доводиться переглядати історію літератури, кардинально міняючи підходи та, як наслідок, оцінки. Особливо складне завдання - утвердження чи заперечення пантеону класиків попередніх епох. Творчий спадок класиків потребує постійного перегляду і розміщення у критичному дискурсі, бо інакше він не відповідатиме потребам сучасності, затвердіє, перетвориться на низку стереотипів чи пам'ятників для риторичного звеличування. Я пропоную перегляд класичного спадку здійснювати в аспекті його місця $\mathrm{i}$ ролі у формуванні національного метанаративу. Останнє поняття - складна і не розроблена тема, яка потребує іншого жанру. В останні десятиліття додаток «мета» з'являється там, де шукаються глибші закономірності: металітература, метамова, метатекст, метажанр, метадрама. Поняття «український метанаратив» виноситься у заголовки сучасних політологічних та історичних студій ${ }^{1}$, а складник «мета» дедалі частіше використовується на позначення різних надконструкцій. На думку дослідниці метадрами О. Вісич, «Численні варіації й не менш численні дебати супроводжують функціонування поняття «метатекст». Серед найвпливовіших концепцій цього феномену залишається його трактування як пояснювального механізму і водночас суголосного явища самосвідомості літератури: обидва підходи фіксують рефлексивність творчості, спрямовану назовні, на пізнання загальних законів буття, або всередину - на розкриття природи творчості. Важливою ознакою метатексту є конденсована літературність, адже він створює особливу комунікативну ситуацію, що змушує сприймати окремі твори як співвіднесені один з одним» ${ }^{2}$.

Ще в середині XX ст. М. Гайдеггер писав: «Останнім часом наукове та філософське дослідження мов щоразу рішучіше зосереджується на

${ }^{1}$ Див.: Горенко О.М. Український метанаратив в епоху пропаганди. Український історичний журнал. 2014. № 2. С. 4-21.

2 Вісич О.А. Метадрама: теорія і репрезентація в українській літературі : монографія. Луцьк : Вежа-Друк, 2018. С. 9-10. 
створенні того, що називають «метамовою». Наукову філософію, що має за мету створити таку надмову, розуміють відповідно як металінгвістику. Звучить як метафізика, і не лише так звучить, а й так $є$; бо металінгвістика - це метафізика суцільного технічного перетворення всіх мов на функціональний міжпланетарний інформаційний інструмент» («Сутність мови») ${ }^{3}$. У 1976 р. вийшла книга А. Тойнбі 3 промовистою назвою: «Людство і колиска-земля. Наративна історія світу». Глобалізаційні процеси, які відтоді прискорюються 3 кожним десятиліттям, змушують гуманітаріїв шукати нові способи дослідження надконструкцій.

Великий фрагментнаціонального наративу твориться письменниками, але не тільки ними. Усе, написане національною мовою, так чи інакше відбиває картину світу, ментальність, національний характер, відносини з іншими народами. У кожному разі йдеться про нерозчинний елемент різних структур, який вказує на витоки дискурсу, маркує явище як належне до чогось більшого. Усі, хто пише однією національною мовою, мають щось спільне, визначене самою мовою. Але ще більш важливий складник - рефлексія над цим спільним, процес самоусвідомлення нації як самодостатнього повновартісного світу, суголосного і водночас відмінного від інших світів.

Мета дослідження - показати необхідність застосування наратологічної та психоаналітичної методології до явищ із розгалуженою і різнорідною будовою: стиль епохи, творчість автора чи низки авторів, об'єднаних естетикою чи іншими рисами творчості, тощо. У такому разі це національний метанаратив у його взаємозв'язку з естетичними пошуками конкретного автора, а саме Олени Пчілки.

\section{1. Роль великих стилів у формуванні метанаративу}

Національний метанаратив - це історія буття і самопізнання народу, розказана його мовою. Складник «мета» вказує на рефлексійну природу текстів, які формують національний метанаратив.

Наратологія як літературознавча наука виробила методологію дослідження, яка успішно застосовується скрізь, де йдеться про особливості подієвого тексту. Але з огляду на дедалі більш інтенсивну взаємодію методологій і обмін ними між різними гуманітарними науками, до власне наратологічного аналізу варто додавати психоаналітичний. Це поєднання ефективне хоча б тому, що поняття «наратив» широко використовується у психоаналізі, оскільки психоаналітики, як і письменники та літературознавці, завжди мали

${ }^{3}$ Гайдеггер М. Дорогою до мови / пер. 3 нім. В. Кам’янця. Львів : Літопис, 2007. C. 136 . 
справу 3 історіями, які люди розказують про себе (усно чи письмово), шукаючи пояснень чи розуміння. Наратологічний аналіз, як i, зрештою, структуралістський, надто формалізує об'єкт дослідження, випускаючи 3 поля зору його змістовність i, зрештою, художність як феномен індивідуальної творчості. Поєднання із психоаналітичним методом дозволить тримати в полі зору мотиваційну сферу процесу творчості та відчитувати ті прошарки змісту, які майже невидимі при формалізованому аналізі.

На мою думку, національний метанаратив має пройти три обов'язкові стадії формування: романтичну, реалістичну, модерністську (у такому сенсі доречний до всіх трьох понять додаток «мета»). Романтичний метанаратив призначений для героїзації минулого, створення національної міфології та пантеону національних героїв. Так усвідомлюється нація як тривала історія i важливий шлях. Реалістичний - для критичного осмислення сьогодення, яке дозволяє планувати майбутне, жити самостійно. Етап усвідомлення влаштованого соціального життя як прояв національної дорослості. Модерністський метанаратив розбиває надто узагальнену історію нації на тисячі індивідуальних шляхів, скеровує кожного до самопізнання. У цьому процесі важливий складник самоусвідомлення індивіда - національна ідентичність. Неналежне опанування культурою будь-якого 3 цих етапів свідчить про глобальні поразки у національному становленні.

Німецькі ідеалісти відкрили світ людської суб'єктивності, яка суттево змінюе речі, досяжні для нашого пізнання. Романтики підготували грунт для постання реалізму: уся європейська культура у середині XIX ст. почала перейматися правдивим зображенням життя. Успіхи природничих i технічних наук переконували в існуванні об'єктивних знань, опанування якими одразу дає результат у вигляді технічного прогресу. Щоправда, самого лише бажання наслідувати життя у формах самого життя виявилось замало. При найстараннішому документалізмі, списуванні 3 реальності картинки 3 життя далеко не завжди виглядали переконливо.

Науку правдивого зображення життя кожен мусив опанувати посвоєму, але й разом з усіма сучасниками, спираючись не так на світовий, як на національний досвід. Кожній літературі у свій особливий спосіб треба було навчитися розказувати історії так, аби вони могли переконати читача у достовірності розказаного.

Найважливішим відкриттям реалістичної техніки став всевідаючий наратор, оповідь від третьої особи, тієї незримої особи, яка має необмежені права у справі зміни точок зору, фокусів зображення, вибору деталей і способів їх поєднання, інтонації, темпу, розстановки усіх маркерів i акцентів, тощо, тощо, але водночас захована від 
читацького погляду, повністю розчинена у мові. Насамперед треба було позбутися інтонацій романтичного наративу, сформованого під впливом усної традиції. Реалістичний наратив, власне, тільки тоді почав служити усім національним оповідачам доброю школою майстерності, коли вповні викристалізувався як спосіб розказування, відмінний від романтичного. Нового наратора треба було відмежувати від ліризованого, емоційного й упередженого романтичного оповідача, хоча й учасника чи навіть героя захопливих подій, але, незалежно від сюжету і міри трагізму, невиправного казкаря, котрий веде читача у світ вигадки й фантазії. Не-казкар, тобто свідок невигаданих подій (у глибокому дискурсі це літописець, або першоавтор геройчного епосу), мусить позбутися усіх емоційних складників власного сприйняття, всіх елементів, що видають в оповідачеві надміру зацікавленого інтерпретатора подій.

Головна проблема опанування реалістичним наративом у поєднанні складної техніки побудови оповіді з невимушеністю, яка робить наратора непомітним. Дуже помітною присутність оповідача (якщо він не персонаж) роблять дві речі - емоційність та іронія. I це ті дві речі, які стали окрасою романтичного наративу, забезпечили йому популярність, стали умовою успішної взаємодії з читачем. Позбутися й одного, й іншого тому, хто вже опанував якийсь прозовий епічний жанр, дуже нелегко. Але навіть вступаючи в літературу в часи реалізму, кожен початківець, так чи інакше, ніс у собі залежність від національного наративу, який його формував. Усі українські прозаїки, які взяли у другій половині XIX ст. курс на реалізм, надто залежали від наративу романтиків i навіть не підозрювали тих небезпек, які криються в залежності від нього. Усе доводилося відкривати інтуїтивно, внаслідок копіткої праці шліфування/припасовування.

Реалістична наративна техніка, яку опановує Олена Пчілка і багато інших прозаїків кінця XIX ст., на мій погляд, може бути вивірена принципом езкистенційного психоаналізу, який дедалі частіше доповнює класичний психоаналіз, але свого часу був сформульований М. Гайдеггером: принцип «тут і зараз» (праця «Буття $\mathrm{i}$ час» ${ }^{4}$ ). Це найбільш відомий i водночас переконливий варіант відповіді на питання І. Канта, котрий піддав сумніву існування об'єктивної реальності. Людська спільнота витрачає значні інтелектуальні зусилля у пошуках відповіді на питання: «Який світ насправді?». Тривалий час світ був рівно таким, яким надавався до сенсорного сприйняття: світ такий, яким я його бачу, чую, відчуваю. Непояснимі речі мирно

4 Хайдеггер М. Бытие и время / пер. с нем. В. Бибихина. Харьков : Фолио, 2003. 503 c. 
сусідили зі звичними, бо релігійна людина завжди пам'ятала про патронаж вищих сил, які час від часу дають про себе знати через дивовижні чи загадкові речі.

Щоб жити і відчувати життя, як воно $\epsilon$, треба навчитися його сприймати у теперішньому часі. Людина надто легко, непомітно для себе, зісковзує у минуле, пригадуючи втішні чи прикрі події, чи у майбутне, мріючи про щось. Лише теперішнє, обтяжливе й недосконале, випадає 3 iї поля зору. Психологи, відкривши у структурі психіки несвідомі сфери, допомогли збагнути, чому це так. Власне, екзистенціалізм, філософія, зосереджена на вирішенні життєвих проблем кожної людини, виріс не лише із філософії життя, а й $з$ психоаналізу. Чим більше несвідомого у внутрішньому світі, тим більш проблемне життя, кероване ірраціональними силами, тим більш людина схильна містифікувати причини невдач, неуспіху, поразок, вибудовуючи образи нещасливої долі, фатальної жінки чи звабливого спокусника, численні образи ворогів.

«Взаємодія «тут і зараз» (тобто коментарі щодо поведінки людини в цю конкретну секунду), - вважає відомий екзистенційний психоаналітик Ірвін Ялом, - доволі рідкісні у повсякденному житті. <...> У рамках психотерапевтичного сеансу звертання до режиму «тут і зараз» передбачає аналіз спілкування терапевта і пацієнта у цей конкретний момент часу та базується на переконанні, що «терапевтична ситуація - це зменшена модель соціального життя» ${ }^{5}$.

\section{2. Наратив ні особливості прози Олени Пчілки}

Можна досліджувати диспозицію щодо національного метанаративу будь-якого автора, але особливу роль грають оповідні твори, які увиразнили наративну техніку яскравими національними елементами, а також автори, котрі зробили посутній внесок у формування домінантного наративу епохи, в історію самоусвідомлення нації. Олена Пчілка якоюсь мірою прописана в історії української літератури, хоча аналітичний підсумок усіх розвідок про іiі творчість складатиметься 3 переказу сюжетів і злободенності питань, які вона вирішує. На думку М. Легкого, проза Олени Пчілки - «цікаве й неординарне явище в українському літературному процесі кінця XIX - початку XX ст.» ${ }^{6}$. Одностайно іiї пов'язують із реалізмом, але що це за реалізм, якої якості

5 Ялом И. Вглядываясь в солнце. Жизнь без страха смерти / пер. с англ. А. Петренко, Э. Мельник. Москва : Эксмо, 2019. С. 270, 271.

${ }^{6}$ Легкий М. Художня проза Олени Пчілки (історико-літературний шкіц). Украӥна: культурна спадщина, національна свідоміст ь, державніст ь. 2012. № 21. С. 453. 
й особливості, вирішувалося лише на проблемно-тематичному рівні (нові теми, злободенні проблеми).

Проза Олени Пчілки - приклад усвідомленого підпорядкування засобів романтичного наративу новій реалістичній оповіді. Вона цілеспрямовано долає ідеалістичну естетику романтизму, укорінює проблематику у сучасність у межах досягання особистого досвіду, а головне - шукає всевідаючого наратора, здатного максимально об'єктивувати зображення. Особливу увагу вона приділяє оповіді в теперішньому часі.

Наскільки майстерно Олена Пчілка використовує теперішній час, варто розглянути детальніше, на прикладі оповідання «Рятуйте!».

Розповідається історія юної селянки Орисі, яка, перебуваючи кілька місяців на заробітках далеко від дому, потрапила під вплив секти хлистів і зайшла в екзистенційну безвихідь, покінчила життя самогубством.

Історія складається 3 восьми фрагментів, сцен у теперішньому часі із поєднанням діалогів і розповіді, в якій виявляє себе всевідаючий наратор.

Чітка фрагментація сприяє сценічності, властивій теперішньому часу. Ми ніби зазираємо крізь вікно у світ, який існує за межами нашого досягання, але впізнаваний із першої деталі. Картинки із сільського життя в Україні кінця XIX ст., у центральному регіоні. Місце й час події не окреслені, але багато деталей вказує на період, що настав після скасування кріпацтва, але до бунтівливого часу рубежу століть. Ця легка неозначеність оживлює деякі романтичні дискурси, хоч і подолані, але все ще могутні. Всевідаючий наратор вочевидь озирається на усного оповідача романтиків. Знаковий початок: «Хороше! Господи, як хороше співають!.. Сказано, як у раю!.. / Так шепчуться поважніші молодиці, стоячи в церкві...» ${ }^{7}$. I далі в мові оповідача вставні слова «сказано», «мовляв» трапляються доволі часто, відсилаючи до умовного усного оповідача, ніби процитованого, але не способом непрямої мови, а лише вказівкою на факт походження з усної мови. Загалом це мова максимально наближена до героїв події, не цілком діалектна i просторічна, а все ж селянська, далека i від авторської мови. Водночас навіть у діалогах це переважно літературна мова (наскільки вона усвідомлювалася авторами). Багато ознак видає iї штучне походження, оріснтацію на літературні зразки, зокрема ранню прозу Миколи Гоголя, але позбавлену поетичних фольклорних чи яскравих розмовних елементів. Письменниця свідомо формує функціональний тип оповіді, максимально скерований на теперішній час і достовірність, тип оповіді, який не привертає уваги, але вводить у зображення необхідні деталі.

${ }^{7}$ Пчілка Олена. Оповідання. 3 автобіографією. Харків : Рух, 1930. С. 198. 
Отже, вісім фрагментів історії, подані в теперішньому часі, відбуваються у присутності читача. Одразу така фрагментація загострює питання добору і причинно-наслідкової впорядкованості, не байдужої реалістичному зображенню. Читач має побачити пружини, невидимі для учасників події. Перший фрагмент (умовно назвемо його «Свято») - служба у церкві на велике («рокове») свято, коли янгольський спів Орисі та Тетяни зворушив серця прихожан, обід у сім'і Ярошенків. Власне, картина першого фрагменту побудована на контрасті - піднесений дівочий спів, залицяння парубків до дівчат на вулиці, перші ознаки закоханості Орисі й Панька; у другій частині фрагменту сцена підкреслено побутова, зображення простого життя великої селянської родини, достатньо поважної, традиційно патріархальної. «По обіді <...> Явдоха навіть ладанцем покурила в хаті. У нас, бачите, тепер ганчарі навіть такі риночки особливі роблять для цього, 3 покришечкою, а в покришечці дірочки, - то як укинеш жарку, та потім ладанцю, накриєш, от воно й курить хорошенько» ${ }^{8}$. Це приклад характерного для оповідання прийому зміни фокусу зображення: око оповідача спочатку знаходиться в хаті (поруч із Явдохою), а потім віддаляється, робить локус хати частиною неозначеного, але доволі широкого простору, українського, але регіонального. Побутова деталь характеризує спосіб життя персонажів і водночас служить маркером національності, такої риси, як укорінена в побут (отже, глибока) набожність народу. Це мова не авторки, скоріше Явдохи, але за умови, що вона про це розказувала б комусь третьому. Насправді вона лише обкурює хату, не коментуючи влаштування риночки. Риночка 3 ладанцем - ніби й не важлива 3 огляду на сюжет деталь, але вона в'яже дві частини фрагменту, церковну й хатню, у ціле. Перша картина історії цілком ідилічна, але це миттєва (тут і тепер) ідилія бідного життя селянської родини.

Наступний фрагмент (назвемо «Вечорниці») більш експресивний і так само піднесений: на вечорницях Орися показує себе як неперевершена запальна танцівниця. Вечорниці завершуються першим побаченням i зізнанням закоханих, Орисі та Панька. Зав'язується історія піднесеного романтичного кохання, яке, за літературною традицію, мусить випробовуватися. Але в цій історії для закоханих не існує жодних перешкод: кохання взаємне, сім'ї закоханих схвалюють одруження. $\mathcal{C}$ лише невеличка трудність: відсутність грошей на посаг Орисі (дівчина надто молода, старша у великій сім’i) та на саме весілля. Тому логічне продовження - третій фрагмент («Кличуть на заробітки»). Він починається розмовою Орисі та Тетяни про можливе сватання

${ }^{8}$ Пчілка Олена. Оповідання. 3 автобіографією. Харків : Рух, 1930. С. 199. 
Панька та про відсутність грошей. Запросини 3 дальньої економії на ціле літо полоти буряки за непогану плату - вигідна справа для сільських дівчат, ситуація наче йде назустріч героям, пропонує ефективний спосіб вирішення проблеми. Четвертий фрагмент («Перед розлукою») весь діалоговий: обговорення Орисиних наймів, невеличка суперечка 3 батьком, який вочевидь не командує в хаті, але під натиском все ж висловив незгоду: «Таки й молода! Куди ій на бік по заробітках ходить? Ще й хирляве таке!» ${ }^{9}$, і матір'ю, яка прагне заміжжя дочки. Її голос став вирішальним. Завершується фрагмент розмовою Орисі та Панька, засмучених майбутньою розлукою: «- Не покинеш думки? не одцураєшся?.. / - Нi!.. - тихо проказала Орися. / По блідому небі покотилася зоря. Орися кинулась. Немов у серці іï щось торкнуло... Острахом, холодом пройшло по йому» ${ }^{10}$. Остання фраза «вмикає» наратора, присутнього у внутрішньому світі героїні.

П’ятий фрагмент («Дальня сторона») висвітлює картину через два тижні по тому, як дівчата працюють на буряках. Фрагмент складається 3 розмови 3 місцевою дівчиною Харитиною, яка працює поруч із Орисею і палко обурюється «блудом» статевих взаємин. Орися мовчки слухає, бо: «Вона нічого не знає...» ${ }^{11}$. Так само мовчки підкорилася Орися Харитині, коли та повела іiі на збір «братів». Голос Орисі, яка включилася у хоровий спів і одразу була помічена, справив враження i, мабуть, відкрив доступ у нову громаду, але всі перипетії перебування в ній лишилися за кадром.

Шостий фрагмент («Дівчата повернулись») робить читача свідком сцени, коли зароблені гроші визначаються матір'ю Орисі як кошти на скоре весілля. Тут, як і в наступних фрагментах, частіше з'являються репліки внутрішнього наратора: «Говорить кума, а Орися, як тільки перше слово почула про Панька та що думає свататись, то серце в неї замліло, - аж за стіл ухопилася, стоячи...» ${ }^{12}$. Сьомий фрагмент («Сватання») i восьмий («Весілля») максимально насичені описом дивних станів Орисі, якій почав снитися дуже страшний сон (який саме, не розказано). Вона потрапляє в залежність від ірраціональних сил, які тягнуть іiі врізнобіч - кохання до Панька, страх непослуху перед батьками, страх зрадити дане слово, а 3 іншого боку - страх перед гріхопадінням i занапащеною душею. Зрештою внутрішня боротьба так виснажує Орисю, що штовхає до панічної втечі, тобто розпачливого самогубства.

\footnotetext{
${ }^{9}$ Там само, с. 202.

${ }^{10}$ Там само, с. 203.

11 Там само, с. 204.

12 там само, с. 206.
} 
Причинно-наслідковий зв'язок восьми фрагментів (Свято / Вечорниці / Кличуть на буряки / Перед розлукою / Дальня сторона / Дівчата повернулись / Сватання / Весілля) є лінійним, кожен наступний епізод є логічним продовженням попереднього. Історія проста, взята цілком із реальності, але водночас доволі традиційна для романтизму: прекрасна дівчина, кохання, розлука, випробування, смерть на весіллі. Різниця в тому, що для Олени Пчілки серед можливих причин трагедії не існує жодної містики, фаталізму чи долі, хоча фінал так само несподіваний, непередбачуваний. Дбайливе дотримання теперішнього часу (романтична історія завжди посувається в абстрактний простір і час, тобто у минуле) забезпечує ефект присутності. У жодній сцені нема нічого загадкового чи вигаданого. Навіть лихе передчуття, яке одного разу схвилювало Орисю, згадано лише побіжно, як штрих до іï характеру. Але 3 кожним епізодом посилюється не інтрига, яку породжують лихі передчуття романтичної історії, а питання: що там діється всередині цієї прекрасної дівчини? Про що вона думає? Що відчуває? Як оцінює? Складається враження, що Орися лише всотує навколишній світ, але ніколи не аналізує того, що відбувається. Вона надто покірна, надто вразлива, а у підсумку - надто беззахисна. Ніхто не здогадується, що діється всередині Орисі, а тому й допомоги чекати нізвідки. Вражена двома сильними емоціями: коханням і страхом втратити цноту, вона так і не збагнула, що з нею сталося.

Оповідання таким чином остаточно перехиляться до психології. Авторка не намагається широко й детально висвітлювати все, що відбувається в душі Орисі, але ці обмеження в доступі визначені не повноваженнями наратора, а характером героїні, яка «нічого не знає», тобто не усвідомлює того, що 3 нею відбувається. Талановита і чутлива дівчина стає беззахисним приймачем для сильних сторонніх впливів. Не здатна усвідомити, не здатна й вибрати. Ї̈̈ панічна втеча у смерть це вирок романтизму й ідеалізму, задекларованих i, здавалося, піднесено прекрасних, на початку історії.

Технічна складність реалістичного наративу поступається перед складністю психологічною. Саме психологія творчості зруйнувала підмурівок естетики реалізму, відкривши шлях для модерністського суб'єктивованого епосу.

Олена Пчілка, будучи шанувальницею нової української літератури та вдячною ученицею іiі романтичного періоду, 3 самого початку творчого шляху має свідомі письменницькі настанови: данину романтизму віддає у поезії та віршованих жанрах, значною мірою в драматургії, а от прозу скеровує на реалізм, із кожним наступним твором послідовно відпрацьовує непросту техніку реалістичного зображення. Її техніка стала результатом не стільки буквального 
вишколу, скільки суттєвих змін у психології творчості. Романтичне натхнення, сплески емоцій, бажання закликати і повести - усе це, властиве будь-якій людині, котра стала на шлях національного самопізнання, потрібно опосередкувати, підкорити, знайти іншу мотивацію.

Реалістичний твір потребує значних обсягів тексту, тривалої праці, а це, у свою чергу, вимагає іншої, не романтичної, мотивації. Раціонально обраний i зважений задум, навіть вкрай важливий, розчиняється у соціальній проблематиці й опосередковує особистий досвід письменника. Раціональна мотивація не забезпечить високого художнього рівня твору. 3 іншого боку, будь-яка активація емоційної сфери одразу перехиляє оповідь у бік суб'єктивності й романтизму. Отож, балансування між емоційною й раціональною сферами неминуче. Але як знайти рівновагу? Бути об'єктивним і водночас не байдужим?

На мій погляд, підказкою відповіді на це питання може служити назва повісті Олени Пчілки «За правдою»: у цій історії чітким пунктиром позначене авторське розуміння того, що правда - це не очевидність, доступна кожному через досвід, а велика проблема. $\mathrm{He}$ існує однієї правди на всіх, тому марна справа іï шукати. Не так просто дошукатися правди серед людей, які по-різному дивляться на світ, бачать своє, головне - вірять кожен у своє.

У двох творах, повісті «За правдою» й оповіданні «Рятуйте!», Олена Пчілка піднімає питання віри у тому іiі гострому прояві, коли палко віруюча людина стає членом секти і перестає бачити навколишню реальність, точніше, починає бачити іiі якось інакше. Як людина мисляча й прогресивна, Олена Пчілка бачить у релігійному сектантстві небезпеку для неосвіченого народу і хоче застерегти від неї. Про авторське експресивне ставлення до теми говорить і назва оповідання. I все ж навіть за такого доволі певного наміру і загалом просвітницької мотивації, яка не підлягає сумніву, письменниця вирішує проблему дуже делікатно, з максимальним відчуттям іï психологічної складності. Здається, глибша мотивація, захована у психології творчості, все ж була залучена: надто подібні між собою героїні обох, достатньо різних сюжетів. Втім, ці героїні трапляються у кожному прозовому творі письменниці та видають глибші секрети творчості, можливо, не усвідомлені й самою авторкою. Олена Пчілка 3 особливою ніжністю змальовує національний жіночий тип, дівчат-селянок. Відчутний вплив Марусь, Оксан, Катерин, ідеалізованих літературою героїнь із народу, вповні окреслених романтиками, але інший ракурс зображення виказує авторське розуміння, що надмірна ідеалізація підважує їх достовірність. На відміну від попередників, Олена Пчілка наділяє своїх прекрасних 
героїнь досить складною психологією, яка, що важливо, - еволюціонує навіть у межах невеликого оповідання.

Оповідання «Рятуйте!» - трагічна історія про дівчину, яку ніхто не врятував від передчасної смерті. Хто ж винен? Відповідь на це питання веде до осмислення витоків трагедії. $Є$ три версії звинувачення відповідно до надзавдань метанаративу. Для романтика це історія про ідеал, явлений у життя як ангельська врода i талант (Орися природний, або ж стихійний геній), приречені на загибель демонічними силами; для реаліста це історія зведення 3 пуття неосвіченої юнки злочинною сектою, яку варто заборонити, а народ просвіщати. 3 погляду модерніста (а ця думка вже цілком усвідомлена Оленою Пчілкою), це історія нереалізованого митця, бо у патріархальному світі дівчина призначена для шлюбу, а не для творчої реалізації.

Проблема жіночої емансипації, звісно, хвилює Олену Пчілку. Але наратив оповідання не пропонує жодного 3 названих варіантів інтерпретації. Парадокс, але, при всій симпатії до Орисі, яку накидає читачеві оповідач, при співчутті та співпереживанні до неї, жодних певних винуватців іiі смерті не окреслено. Звісно, якби не секта, трагедії не сталося б, але й іï члени не показані злочинцями. Скоріше, це також жертви. Принаймні, два виокремлені 3 цієї спільноти персонажі, дівчина Харитина і старий Назар, котрі вплинули на Орисю, не є винуватцями. Харитина заразила Орисю палкою переконаністю в тому, що статеві стосунки суперечать християнській вимозі цноти. Ймовірно, що Харитина, втративши шанс на заміжжя, знайшла опору у вченні, яке не лише виправдовує, а й підносить незайманість. Власне, весь інститут середньовічного схимництва i монастирів виріс на бажанні дотримуватися цноти як найбільш християнського способу життя. Чому раптом розмови з Харитиною вплинули на Орисю, можна лише здогадуватися. Вона хоч і заручена, закохана, але надто юна, ii страшать стосунки 3 чоловіком, здаються гріховними. Аргументи Харитини щодо подвійності моральних норм, які осуджують тих, хто живе статевим життям без шлюбу, але виправдовують ті самі стосунки лише на підставі церковної церемонії, Орися не змогла заперечити.

Харитині перебування в секті швидше допомогло, ніж зашкодило. Судячи з усього, ій ведеться непогано. Інший персонаж, старий Назар, якого піддали катуванню через секту і який від неї не відмовився, нагадує біблійні історії про святих великомучеників, віру яких піддавали жорстокому випробуванню. Цей жертовний стоїцизм не міг не зворушити чутливу натуру Орисі. Отже, про хлистівство як явище в оповіданні майже не йдеться. Навряд чи вони мали лихі наміри щодо Орисі, та й самі, мабуть, будуть вражені страшним кінцем дівочого життя. 
Чується винною матір дівчини, але іï шкода ще більше, ніж Орисю, адже для неї вчинок дочки не лише трагічний, а й абсурдний.

Власне, цей вчинок, який здається страшною, незбагненною аномалією, наглим порушенням звичного життєвого плину, $\epsilon$ справжнім проявом реальності, тієї правди, яка існує на межі між зовнішнім і внутрішнім світом кожної людини.

Розглядаючи еволюцію американського класика XIX ст. Генрі Джеймса як перехід від реалізму до модернізму, Сінтія Озік зауважує: «Його ранні оповідання й романи схожі на кімнати, у які крізь вікна випромінює світло. Навіть якби туди й потрапила таємниця, іï одразу розплутали б. Загадки людської природи, породжені випадковостями, збігами обставин, похибками в судженні, тремтінням соціальної павутини, інтригами підступного і жорстокого оточення виявляються врешті прозоримий раціональними» ${ }^{13}$. Потрясіння, пережите Джеймсом у житті, змінило його процес творчості. «Відмовившись від голосу оповідача та експозиції й підійшовши натомість до роману як до сценарію, він відкрив (чи винайшов) глибинні лабіринти, які ми згодом ототожнимо злітературним модернізмом» ${ }^{14}$. Сповнені жаху містичні романи Джеймса - історії про руйнацію звичної реальності. Олена Пчілка теж мала у житті чимало травматичних подій, які впливали на ії творчість, але різкого повороту в інший бік вона не зробила. Івсе ж, подібно до Джеймса, вона, максимально об'єктивуючи зображення, в т. ч. за допомогою «сценарності» (так теж можна назвати принцип «тут і зараз»), ставить під сумнів існування спільної для всіх об'єктивної реальності.

Розвиваючи вчення французького психоаналітика Жака Лакана, сучасний словацький вчений Славой Жижек піддає докладному аналізу популярне кіномистецтво, аби провести паралелі між роботою письменника чи режисера, з одного боку, і психоаналітика - 3 іншого. Йдеться про численні прийоми «полювання за реальністю» i iii невловимість. За Лаканом, ми оточені символічною реальністю, яку й сприймаємо як правдиву реальність. Навколишній світ, особливо соціальний, викликає довіру доти, доки він включений у символічну реальність. Але іноді ця звична й незаперечна реальність раптом захитується вторгненням чогось неприйнятного, абсурдного, тієї травматичної події, «яку неможливо інтегрувати у символічну реальність, оскільки вона мовби перериває причинно-наслідкову послідовність. Від моменту iï вторгнення навіть найбуденніші події у житті, здається, набувають загрозливого виміру; буденна реальність перетворюється на

13 Озік С. Що знав Генрі Джеймс / Метафори і пам'ять. Вибрані есеї / пер. 3 англ., упоряд. Я. Стріхи. Київ : ДУХ І ЛІТЕРА, 2014. С. 69.

${ }^{14}$ Там само, с. 82. 
кошмарний сон, де «нормальний» зв'язок між причиною та наслідком більше не діє» ${ }^{15}$. Жижек розглядає насамперед таку класичну для детективного жанру подію, як убивство. Але література споконвіку, починаючи 3 міфології, тяжіє до зображення подій, які «перевертають» життя. І це, переважно, романтичний дискурс у баченні світу. Неймовірна подія витягує романтика 3 повсякденності та занурює у світ пригод. Натомість реаліст використовує травматичну подію як кінчик ниточки, яка приводить до прихованої причини. Руйнація оманливої (можна сказати словами Лакана символічної, а можна й більш відомим у культурі XX ст. поняттям - міфічної) дійсності передує відкриттю справжньої реальності.

Пчілка обриває свою історію на травматичній події. Ї̈ героїня не змогла припасувати нову реальність до звичного символічного порядку, тому іiі світ зламався. «Парадигматичним підсумком такої драми $\epsilon$ в кінцевому підсумку Едип: коли він нарешті дізнається правду, він «екзистенційно втрачає грунт під ногами» і зависає у незносній порожнечі» ${ }^{16}$, вважає Жижек. Так само зависла в екзистенційній порожнечі Орися. Дві символічні реальності не поміщаються в одному внутрішньому світі, утворюють конфлікт, який руйнує основи психічного життя.

Але для читача трагічний кінець історії мусить стати початком усвідомлення тих сфер, які знаходяться за межею сенсорного сприйняття, але складають правдиву реальність внутрішнього життя.

\section{ВИСНОВКИ}

Олена Пчілка свідомо оволодіває принципом зображення «тут і зараз», у сьогоднішній культурі пов'язаного з екзистенційним психоаналізом. Внаслідок досягнень філософії і психології XX ст. утвердилося розуміння глибинного зв'язку між наративом у теперішньому часі та психічними процесами. Саме теперішній час стає умовою адекватного сприйняття самого себе, початком процесу самоусвідомлення. Олена Пчілка відкриває завісу над внутрішнім життям людини, моделює психіку як динамічний конфлікт між внутрішнім і зовнішнім світом, розглядає парадокс суб'єктивної правди. Специфіка психологізму прози Олени Пчілки напряму пов'язана 3 особливостями ii оповіді. Вона збагатила національний метанаратив переконливими картинами життя, насиченими численними деталями, що $€$ внеском у реалізм, але водночас, моделюючи психологію персонажа, письменниця робить акцент на суб'єктивності світосприйняття і тим самим включається у премодерністський процес.

15 Жижек С. Погляд навскіс. Вступ до теорії Жака Лакана через популярну культуру / пер. з англ. П. Шведа. Київ : Комубук, 2018. С. 106.

${ }^{16}$ Т ам само, с. 82 . 
Автори, які зробили внесок у створення способу достовірного зображення внутрішнього і зовнішнього життя національно ідентичної людини, є співавторами національного метанаративу. В їх числі Олена Пчілка. Усі іï наративні знахідки будуть підхоплені, втілені й реалізовані у прозі і драматургії Лесі Українки.

Переконана: слабкий реалістичний метанаратив i досі негативно відгукується в бутті українського народу. Численні заборони на пр авду в умовахнаціональноїзалежності стали суттєвою перешкодою для розвитку цього напряму. Те, що саме реалізм в історії української літератури був найбільш загроженим явищем, стало мінус-досвідом, який потім довго і складно надолужувався. Достатньо героїчної самопожертви, наснаженої романтизмом, достатньо творчого креативу, оригінальності та розмаїття, заснованих модернізмом, бракує критичного бачення самих себе.

Тому варто вертатися до творчості реалістів, особливо тих, що тривалий час перебували у тіні, як Олена Пчілка, аби реалістична естетика стала більш усвідомленою у сучасній культурі. Хоча реалізм як художній напрям відійшов у минуле, реалістична техніка і психологія реалістичного типу творчості не зникають, вони лишаються такими ж важливими, як i були. Національний метанаратив продовжує формуватися. Постмодерністський період у культурі - це суміш усього, що колись було знайдено і втілено. Аби культура у своєму еклектизмі не розсипалася на хаотичне нарощування необов'язкових фрагментів, вона змушена шукати опертя у глибинних магістральних напрямках руху. Іншими словами, цілісності культурі, як i раніше, як i завжди, надає національний метанаратив із романтичним, реалістичним імодерністським наративами у складі.

\section{АНОТАЦІЯ}

У статті пропонується розглядати наративні особливості прози конкретного автора в диспозиції до національного метанаративу. Стверджується, що національний метанаратив має пройти три обов'язкові стадії формування: романтичну, реалістичну, модерністську. Пропонується до наратологічного аналізу додавати психоаналітичний підхід. Стверджується, що Олена Пчілка, оволодіваючи технікою реалістичного наративу, свідомо орієнтується на принцип зображення «тут і зараз», у сьогоднішній культурі пов'язаного 3 екзистенційним психоаналізом. Специфіка психологізму прози Олени Пчілки напряму пов'язана 3 особливостями іï оповіді.

\section{ЛІТЕРАТУРА}

1. Вісич О.А. Метадрама: теорія і репрезентація в українській літературі : монографія. Луцьк : Вежа-Друк, 2018. 340 с. 
2. Гайдеггер М. Дорогою до мови / пер. 3 нім. В. Кам'янця. Львів : Літопис, 2007. 232 с.

3. Горенко О.М. Український метанаратив в епоху пропаганди. Украӥнський історичний журнал. 2014. № 2. С. 4-21.

4. Жижек С. Погляд навскіс. Вступ до теорії Жака Лакана через популярну культуру / пер. з англ. П. Шведа. Київ : Комубук, 2018. 320 с.

5. Легкий М. Художня проза Олени Пчілки (історико-літературний шкіщ). Україна: культурна спадщина, начіональна свідомість, державність. 2012. № 21. С. 483-491.

6. Озік С. Що знав Генрі Джеймс / Метафори і пам'ять. Вибрані есеї / пер. $з$ англ., упоряд. Я. Стріхи. Київ : ДУХ І ЛІТЕРА, 2014. С. 68-93.

7. Пчілка Олена. Оповідання. 3 автобіографією. Харків : Рух, 1930. $288 \mathrm{c}$.

8. Хайдеггер Мартин. Бытие и время / пер. с нем. В. Бибихина. Харьков : Фолио, 2003. 503 с.

9. Ялом И. Вглядываясь в солнце. Жизнь без страха смерти / пер. с англ. А. Петренко, Э. Мельник. Москва : Эксмо, 2019. 384 с.

Information about the author: Moklytsia M. V.,

Doctor of Philological Sciences, Professor, Head of the Department of Theory of Literature and Foreign Literature Lesya Ukrainka Eastern National University 13, Volya Avenue, Lutsk, 43025, Ukraine 